\title{
Impact Of Taxation On The Performance Of Small And Medium Enterprises In Aba, Abia State, Nigeria
}

\author{
Godswill Agu Agu \\ Department of Marketing, \\ Abia State University, Nigeria \\ Onwka Okwara Onwuka \\ Department of Accounting, \\ Abia State University, Nigeria \\ Obinwanne Aruomah \\ Department of Accounting, \\ Abia State University, Nigeria
}

\begin{abstract}
This work aims at assessing the effect of taxation on the performance of SMEs in Aba Abia State. A survey approach was adopted while the questionnaire was used as an instrument. A randomly selected 162 employees and owners of 40 SMEs were used for the study. Collected data were analyzed using the multiple regression analysis and one sample t-test. Results indicate that significant and positive relationship exist between taxation and the performance of SMEs and that tax assessment, tax collection and tax utilization significantly influence the performance of SMEs in Aba. It was recommended among others that the Nigerian tax system must seek to protect and promote the SMEs for them to contribute meaningfully to economic growth and that they should identify the agents responsible for illegal, multiple tax collections that seek to frustrate SMEs and deal with them accordingly.
\end{abstract}

Key Words: Taxation, Performance, SMEs.

\section{INTRODUCTION}

Economic growth and development have become near synonyms to small and medium scale enterprises (SMEs) in countries where adequate level playing ground is provided for entrepreneurs. SMEs have been described as essential agents for delivering more inclusive globalization and growth, and key contributor to economic and social wellbeing (OECD, 2017). According to the OECD (20016) report, in the OECD area, SMEs are the pre-dominant form of enterprise, accounting for approximately $99 \%$ of all firms. They provide the main source of employment, accounting for about $70 \%$ of jobs on average, and are major contributors to value creation, generating $50 \%$ to $60 \%$ of value added on average. Corroborating with this is IFC (2010) as contained in the OECD (2017) report which asserts that for emerging economies, SMEs contribute up to 45\% of total employment and 33\% of GDP. According to the Small and Medium Enterprises Development Agency of Nigeria (2013) and the National Bureau of Statistics (2013), there were 37,067,416 (Thirty Seven Million, Sixty Seven Thousand, Four Hundred and Sixteen) Micro, Small and Medium Scale Enterprise in Nigeria as at 2013 which employed over $84 \%$ of the total labour force, and contributing $48.47 \%$ to the Gross Domestic Product (GDP). Today, 96\% of businesses are SME's compared to $53 \%$ in the US and $65 \%$ in Europe (IFC, 2018). This, the International Council for Small Business (ICSB) affirms by asserting that MSMEs make up over $90 \%$ of all firms and account for an average of $50 \%$ GDP of any economy. 
Given these global recognitions on the value of MSMEs in any economy, Nigeria inclusive, one wonders why SMEs in Nigeria struggle to survive and achieve these global goals. As rightly observed by Banji (2017), key building blocks for an enabling SME business environment in Nigeria include: basic science and technology knowledge base, legal and regulatory structure, basic physical and technological infrastructure and financial incentive structures. A key factor in the legal/regulatory and financial incentives structures is the tax system on the SMEs. Studies have shown that tax related issues have resulted in untimely exit of many SMEs in Nigeria. SMEDAN (2015) records that, 80\% of SMEs in Nigeria die before their fifth year as a result of challenges faced by start-ups. Ochani and Gamade (2018) observed that multiple taxation and economic tax burdens have remained major challenges to SMEs. In fact when the tax system on Nigerian SMEs is weighed against the ancient Canons of equity, certainty, economy and convenience as enshrined in the Adam Smith's "Wealth of Nations" of 1776, it will be obvious that the system does not adequately support the SMEs to play their role. The Delloitte Nigeria SMEs report (2018) discloses that the Nigerian government tends to focus more on the welfare of large corporations with foreign investments to the detriment of the SMEs which are wrongly perceived to have insignificant impact on the economy. OECD, (2017) captures that SMEs have a high propensity to transform an economy if a conducive environment is created for them to grow through appropriate regulation and tax policies. The Delloitte report (2018) states, "In Nigeria, SMEs are subjected to multiple taxes by the different tiers of government, each with its own rigorous process and significant compliance cost. Considering the size of their operations, the absence of harmonized tax regime increases the strain on cash flow and other limited resources of SMEs when compared to large corporations".

The plight of SMEs in the face of the unfriendly tax policies being experienced and the effect of the scenario on the economy make this study imperative. There is the need to find out how the tax system has affected the financial and non-financial perform indicators of these SMEs judging from perceptions of the key players in the firms. Unlike extent studies that used pure secondary data, this study is based on primary sources in order to ascertain the perceptions, feelings and views of the entrepreneurs, owners of the SMEs and their managers on the subject matter. Again, this study compares both financial and non-financial performance indicators of SMEs to ascertain the impact of taxation on them. This is much unlike previous studies that either focused on pure financial indicators or non-financial indicators.

\section{The Problem}

Taxation is expected to contribute significantly and positively to the performance of SMEs in any economy. This however, seems to be largely far from reality in the Nigerian scenario, the establishment of the new National Tax Policy (NTP) which seeks to create robust and efficient tax system with focus on legislative amendments to reduce tax burden on MSMEs, notwithstanding. An interaction with most entrepreneurs in Nigeria shows a high level of displeasure with the tax system, especially at the state and local government levels. In most instances, thugs are used to harass and intimidate business owners to force them to pay, even in situations where it is obvious that such laws (taxes) are illegal and multiple. The level of corruption in the tax assessment, administration and utilization has denied the SMEs the benefit they ought to derive as tax payers. The Delloitte report (2018) has it that "...businesses that make profits are usually subjected to multiple taxation in their first three years of commencement due to the rules for taxation of a new business; thereby increasing the risk of failure of SMEs within the first few years of business. Also, exemption of companies with at least 25\% imported equity from minimum tax is discriminatory to Nigerian owned businesses. More notably, it discourages investment and increases the risk of failure for 
companies in periods of little or no profitability in the case of SMEs. In the same vein, a good number of SMEs are not able to adequately benefit from tax incentives due to the small size of their operations".

With a substantial fixed cost component to tax regulatory requirements and compliance costs (record keeping, filing and payment processes etc.) at national, regional and municipal levels, small businesses are at a disadvantage with respect to large enterprises. For young firms, which also tend to be small, high compliance costs can exacerbate the resource and cash-flow constraints often experienced in the early stages of business development, and may act as a deterrent to formalization. In some cases, tax compliance costs for small firms may even exceed their tax cash payments (OECD 2015c; Eichfelder and Vaillancourt, 2014). Furthermore, certain aspects of business taxation, including asymmetric treatment of profits and losses, the distribution of taxation between capital and labour income and the design of R\&D tax credits and incentives, can unintentionally disadvantage some young and small firms (OECD, 2015c).

Given this situation one doubts the ability of Nigerian tax system on SMEs to encourage greater investments, transition from informal to formal, and impact significantly and positively on employment generation, sales revenue, innovativeness and profitability of the firms.

\section{Study Objectives}

This study aims at assessing the impact of taxation on the performance of SMEs in Aba, Abia State. The specific objectives are:

1. To know whether significant and positive relationship exists between taxation and SMEs performance.

2. To know whether the tax assessment system in Aba affects the performance of SMEs significantly.

3. To determine whether the tax collection system in Aba significantly affects the performance of SMEs.

4. To ascertain whether the tax utilization system in Aba significantly influence the performance of SMEs.

\section{Scope of the Study}

The geographical setting of this research study is Abia State Nigeria with particular attention on SMEs operating in Aba. This study is domiciled in the areas of entrepreneurship and corporate performance. The units of analysis in the study are owners, managers, marketers and accountants of select firms from the cosmetic, paint, shoes, chemical and clothing segments. Forty firms were chosen for the study. Abia State and indeed Aba is thickly populated with MSMEs in the various sectors of the Nigerian economy.

\section{Concept of Taxation}

Taxation is the primary source of governmental revenue. It is the act of laying a tax, i.e., the process by which a local, state and central government, through its law-making body, raises revenue to defray the necessary expenses of the government. According to Anyanwu (1997), taxation can be defined as the compulsory transfer or payment (or occasionally of goods and services) from private individuals or groups to the government. Agyei (1983) as cited in Ekine (2007), defines it as the transfer of resources from the private sector to the public sector in order to accomplish some of a nation's economic and social goals.

The purpose and importance of taxation is to raise funds with which to promote the general welfare and protection of a nation's citizens, and to enable it to finance its multifarious activities and to redistribute wealth and management of the economy (Jhingan 2004, Bhartia, 
2009; Ola (2001) cited in Ogbonna and Ebimobowei,2012). Jhingan (2002) and Anyanwu (1993) pointed out several objectives of taxation, which include to:

i. Put a curb on consumption and thus transfer resources from consumption to investment

ii. Raise revenue for government

iii. Reduces economic inequalities and

iv. Control income and employment.

\section{Challenges of Tax System in Nigeria}

The Nigeria tax system is beset by a myriad of challenges, some of which are highlighted below (FRN i1997, 2002; Ariyo 1997; Ola 2001; Odusola 2002, 2003; study group on tax reform 2003): non availability of tax statistics; inability to prioritize tax effort; poor tax administration; multiplicity of tax; regulatory challenges; structural problems in the economy; corruption; complexity of tax laws:

\section{The Concept of Small and Medium Scale Enterprises}

The Nigeria Bank for Commerce and Industry (as cited in Jimah, 2011) defined a small scale enterprise as one whose capital does not exceed $\$ 750,000$. The above definition plays emphasis on the capital requirement in the formation of the business. Though capital is not the only consideration in determining whether a business venture is a SMEs or not.

Agu (2001) defined SMEs as a business which is owned, led by one or a few persons, with direct owner(s) influence in decision making, and having a relatively small share of the market and relatively low capital requirement. Osazee and Anao (as cited in Inegbenebor, 2006) defined a small scale business is any business undertaken, owned, managed and controlled by not more than two entrepreneurs, has no more than twenty employees, has no definite organizational structure (that is, all employees report to the owners) and has a relatively small share of its market. In a similar vein, Inegbenebor (2006) opined that the current industrial policy of Nigeria, Small and Medium Scale Enterprises (SMEs) are now defined on the basis of employment. That is:

i. Micro/cottage industries

1 and 10 workers

ii. Small - Scale Industries

11 and 100 workers

iii. Medium Scale industries

101 and 300 workers

iv. Large scale industries

301 and above

\section{THEORETICAL FRAMEWORK}

Many theories of taxation exist. However, in this study, the Benefit Principle or received theory: Also called vertical equity. Richard and Peggy (1973) noted that the benefit approach was initially developed by two economists of the Stockholm School; Knut Wicksell (1896) and Erik Lindahl (1919). This was in a bid to assess the efficiency of taxes and appraising fiscal policy. Thus, the theory stipulates that an individual ought to be taxed according to the benefits received from government provision of goods and services. This in other words, is a benefit cost approach in which tax is a cost and government amenities are the benefits (Bhartia, 2009; Anyanfo, 1996). This theory assumes a state of equality between the marginal tax rate (MTR) and marginal benefit received (MBR) to determine the amount of taxes to be paid (Bhartia, 2009). This is the basic philosophy that ought to guide taxation in Nigeria. This seems to be farfetched. 


\section{Empirical Framework}

The study of Bosco (2011) aimed at assessing the performance of business enterprises in Ntungamo Town Council, finding out if tax payers are aware of all their tax obligations, policies and problems affecting them as well as their businesses. The findings revealed the problems faced by the tax payers as regards mode of assessment, collection and tax collectors, inefficiency by tax collectors, loss of equipment, loss of sales and loss of stock as a result of taxes. Adebisi and Gbegi's (2013) examined the effect of multiple taxation on SMEs survival. The study involved a survey research design with a population of 91 . The researchers derived their sample size to arrive at 74 and a self administered questionnaire was used to collect data. These data were quantitatively analyzed with simple percentages and tested the research hypothesis with ANOVA. Findings revealed that multiple taxation has negative effect on SMEs' survival and the relationship between SMEs' size and its ability to pay taxes is significant. We therefore recommends that government should come up with a uniform tax policies that will favour the development of SMEs in Nigeria and government should put into consideration the size of SMEs when setting tax policies.

The study of Abata (2014) focused on the impact of tax revenue on Nigeria economy. Descriptive survey design was adopted and simple random sampling technique was used in the selection of the sample size. The findings show that tax revenue significantly impact on Federal Government Budget implementation in Nigeria, Tax administrative system significantly affected the revenue generated in Nigeria, Tax evasion significantly affected government revenue in Nigeria, and Lack of training on the part of tax officers significantly affected the generation of government revenue in Nigeria.

\section{Conceptual Framework:}

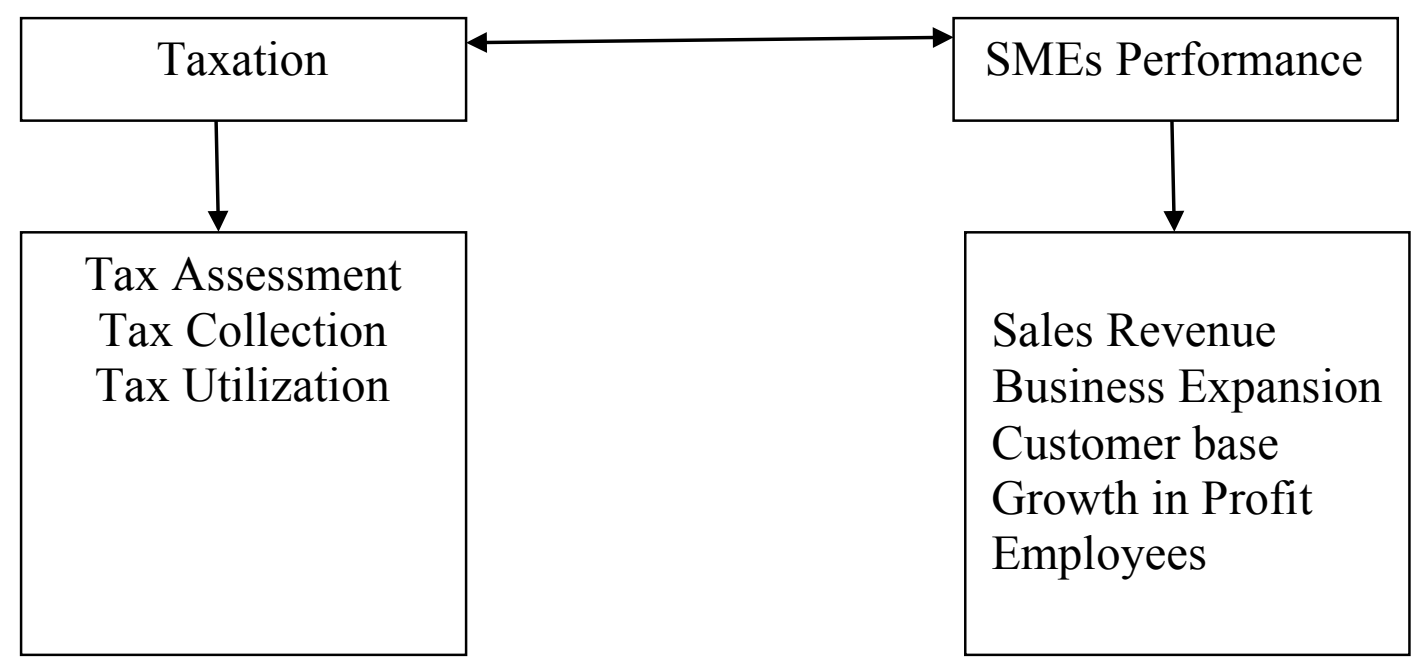

Based on these, we hypothesized thus:

H01: There is no significant and positive relationship between taxation and SMEs performance in Aba.

\section{RESEARCH METHODOLOGY}

In this study, the survey research design was adopted. The study population is made up of SMEs in Aba Abia State. Records from the Aba Chambers of Commerce show that a good number of the MSMEs are not duly registered members. Thus, the exact population of the manufacturing firms was unknown. However, our interest is on 40 manufacturing firms from 
the chemicals, paint, shoes clothing and cosmetic segments. Hence, the sample size was drawn from the management, marketing and accounting units of the firms. Respondents were chosen from each of the 40 firms. Based on convenience reasons, the firms were selected. The researchers adopted the non-probability sampling technique, where units of analysis were selected based on convenience and availability. Copies of the questionnaire were issued through the company secretaries/receptionist to the managers (owners), marketing executives and accountants of the firms, and were retrieved after three working days. Majority of the firms are allocated within the industrial clusters of Osisioma and Ariaria.

Topman formula as cited by Ogbuji (2013) was applied to arrive at a sample size of 162 . Thus:

Table 1: Sectoral Distribution of Sample Size

\begin{tabular}{|c|c|c|c|}
\hline SNo & Sector & Number & Sample Size \\
\hline 1. & Chemicals & 6 & $4^{*} 6=\mathbf{2 4}$ \\
\hline 2. & Paint & 4 & $4^{*} 4=\mathbf{1 6}$ \\
\hline 3. & Shoes & 22 & $4^{*} 22=88$ \\
\hline 4. & Clothing & 4 & $4^{*} 4=\mathbf{1 6}$ \\
\hline 5 & Cosmetics & 4 & $4^{*} 4=\mathbf{1 6}$ \\
\hline & Total & $\mathbf{4 0}$ & $\mathbf{1 6 0}$ \\
\hline
\end{tabular}

Source: Researcher's Computation, 2018.

\section{Reliability and Validity of Instrument}

The likert scale on dependent and independent variables are subjected to Cronbach Alpha test to ascertain the reliability of the instrument. This was done using the responses of the 10 respondents who were issued the questionnaire on a pilot test. The table below shows the result of the Cronbach Alpha test and the factor loading.

Table 2: Reliability and Validity of Instrument

\begin{tabular}{|c|c|c|c|c|}
\hline S/No & Variable & No. of Items & Cronbach Alpha & Factor Loading \\
\hline 1 & Tax assessment & 3 & 0.732 & 0.711 \\
\hline 2. & Tax collection & 3 & 0.721 & 0.685 \\
\hline 3. & Tax utilization & 3 & 0.835 & 0.622 \\
\hline 4. & Firm performance & 5 & 0.751 & 0.756 \\
\hline
\end{tabular}

Source: SPSS Output, 2018.

The result shows that all the variables met the minimum threshold for acceptance since they are up to $70 \%(0.70)$. Based on the factor loadings, the instrument was se.

The equation for linear regression takes the form: $Y=\alpha+\beta X+e$

Where: $\alpha=$ the $Y$ intercept, $\beta=$ the regression coefficient for the independent variable X. $\mathrm{Y}=$ the dependent/criterion variable (firm performance)

$\mathrm{X}=$ the independent/predictor variables (taxation) that influence the dependent variable.

The direct effect research model for this study is of the form:

$\mathrm{FP}=\mathrm{f}(\mathrm{T})$.

Where:

FP is Firm Performance and T is Taxation. 


\section{Model Specifications}

The necessary models for our regression analysis are implicitly specified as followed:

Where:

$$
\text { Firm performance }=f(\mathrm{TA}+\mathrm{TC}+\mathrm{TU}+\mathrm{e})
$$

$\mathrm{TA}=$ tax assessment

$\mathrm{TC}=$ tax collection

$\mathrm{TU}=$ tax utilization

The composition, direction and relative strength of each of the three independent variables on the single dependent variable (performance) would be determined.

\section{Decision Rules:}

In order to validate (accept) or nullify (reject) any stated hypothesis tested with the multiple regression, major attention was paid to the P- values of the tested constructs. Therefore, we rejected the null hypotheses where the SPSS p-values are less than alpha (0.05) and the alternative hypotheses accepted.

Also, the t-test was used ascertain the present tax system in $\mathrm{Aba}$, in the opinion of the respondents, influence their firms' performance. Where the t-calculated is more than $t$ tabulated value, the null hypotheses will be rejected otherwise it will be accepted.

Table 3: Distribution and Retrieval of Instrument

\begin{tabular}{|c|c|c|c|c|c|}
\hline $\begin{array}{c}\text { Number of } \\
\text { Copies } \\
\text { Distributed }\end{array}$ & $\begin{array}{c}\text { Number of } \\
\text { Copies } \\
\text { Retrieved }\end{array}$ & $\begin{array}{c}\text { Number of } \\
\text { Copies Lost }\end{array}$ & $\begin{array}{c}\text { Number of } \\
\text { copies found } \\
\text { useful }\end{array}$ & $\begin{array}{c}\text { Number of } \\
\text { discarded } \\
\text { copies }\end{array}$ & $\begin{array}{c}\text { Percentage of } \\
\text { Retrieved and } \\
\text { Used Copied }\end{array}$ \\
\hline 162 & $153(94 \%)$ & $9(7 \%)$ & 148 & 5 & 91.00 \\
\hline
\end{tabular}

Source: Field survey, 2018.

Table 3 shows that out of the 162 copies of the questionnaire distributed, 153 (94\%) copies were retrieved while $9(7 \%)$ copies were lost. Also, of the 153 copies retrieved, 5 copies were incompletely filled and therefore were discarded. However, 148 (91\%) copies were completely filled and found useful for analyses. Thus, further analyses in this study were based on the 148 copies retrieved and found useful.

Table 4: Designation of Respondents

\begin{tabular}{|l|c|c|}
\hline \multicolumn{1}{|c|}{ Option } & Frequency & Percentage \\
\hline Directors/Owners & 40 & 27.00 \\
\hline Marketing Managers & 70 & 47.00 \\
\hline Accountants & 38 & 26.00 \\
\hline Total & 148 & $\mathbf{1 0 0}$ \\
\hline
\end{tabular}

Source: Field survey, 2018. 


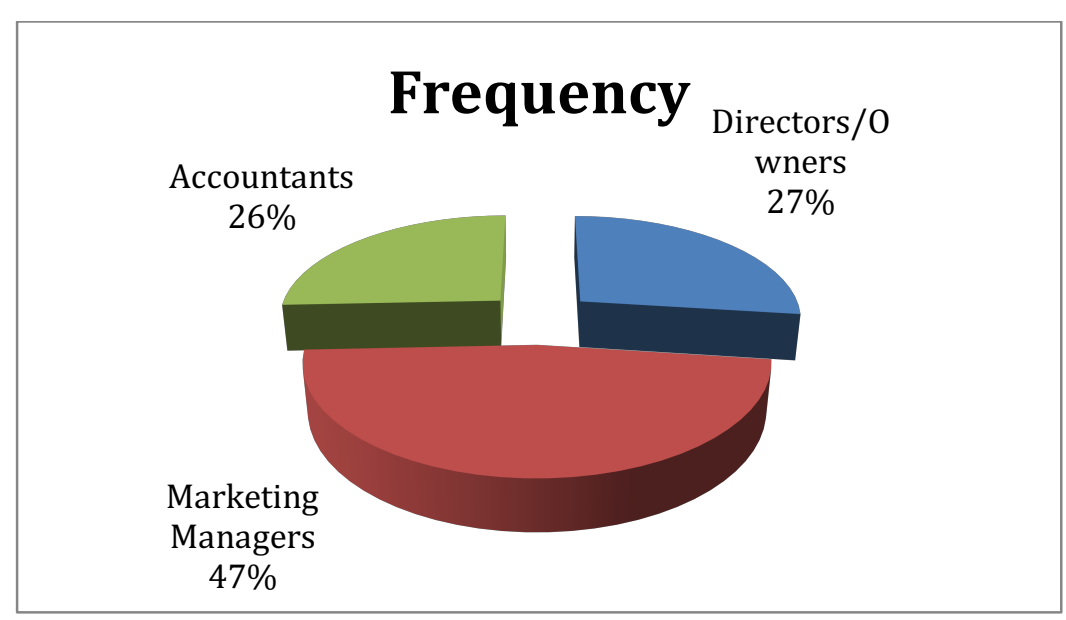

Figure 4.1:Pie chart showing the designation of the respondents

\section{Analysis of Demographic Variables of Respondents}

In this section, all the demographic questions in the questionnaire were analyzed. This section covers responses to questions $1,2,3,4$, and 5 .

Table 5: Demographics of the Respondents

\begin{tabular}{|c|c|c|}
\hline Option & Frequency & Percentage \\
\hline Gender: & & \\
Male & 80 & 54.00 \\
Female & 68 & 46.00 \\
\hline Age Bracket: & 29 & \\
$18-25$ & 34 & 20.00 \\
$26-35$ & 49 & 23.00 \\
$36-45$ & 36 & 40.00 \\
46 years and above & 19 & 24.00 \\
\hline Educational Qualification & 47 & 13.00 \\
FSLC & 47 & 32.00 \\
O'Level/ND & 30 & 32.00 \\
HND/BSC & 05 & 20.00 \\
Masters and above & 75 & 03.00 \\
Others & 61 & 51.00 \\
Marital Status & 12 & 41.00 \\
Married & & 08.00 \\
Single & 38 & \\
Others & 50 & 26.00 \\
\hline Less than 5 years & 40 & 34.00 \\
5 - 10 years & 20 & 27.00 \\
11 - 15 years & & 13.00 \\
\hline
\end{tabular}

Source: Field Survey, 2018. 
This information is further presented in the following figures:

\section{Gender of Respondents}

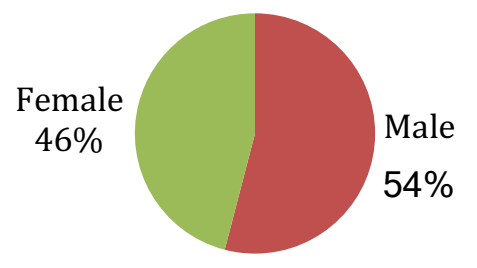

Figure 4.2: Pie chart showing gender of the respondents

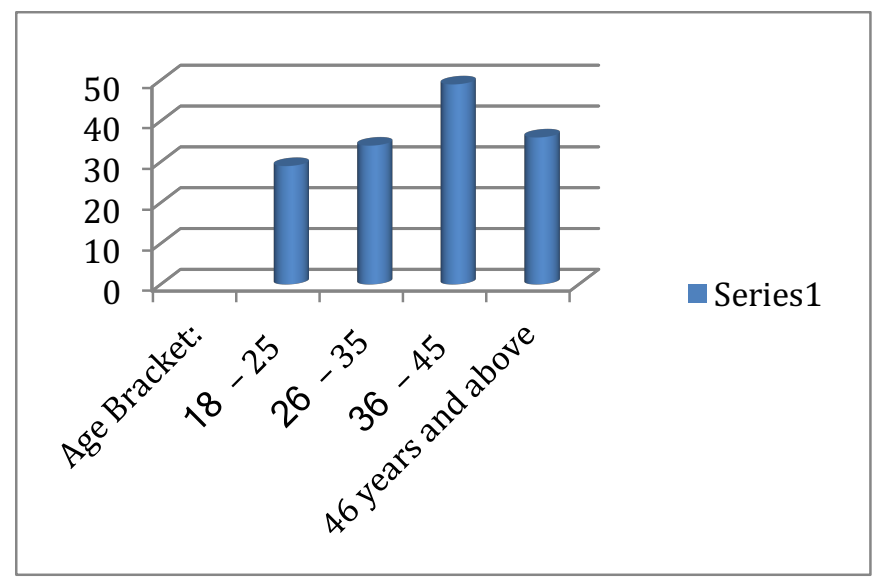

Figure 4.3: Column graph showing age of the respondents

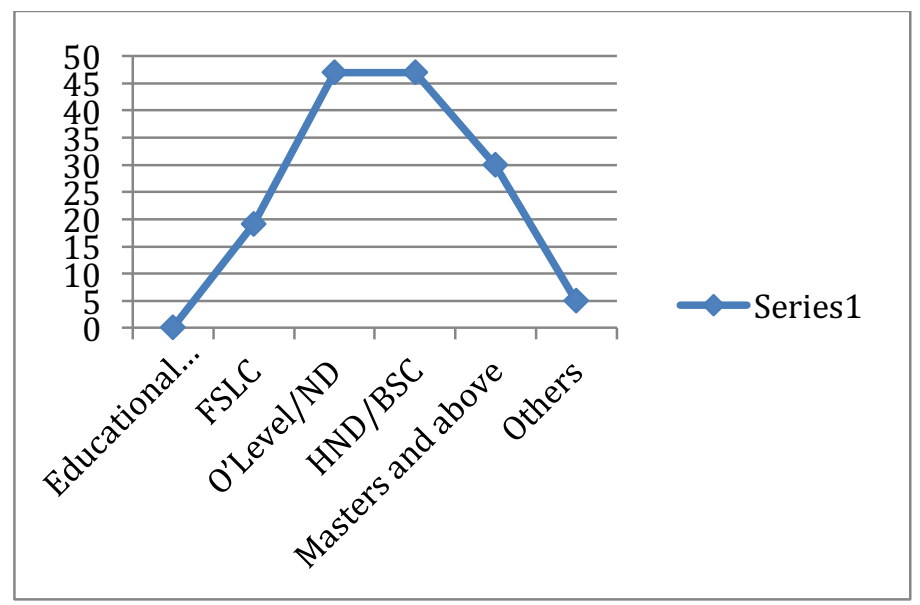

Figure 4.4: Line graph showing educational qualification of the respondents 


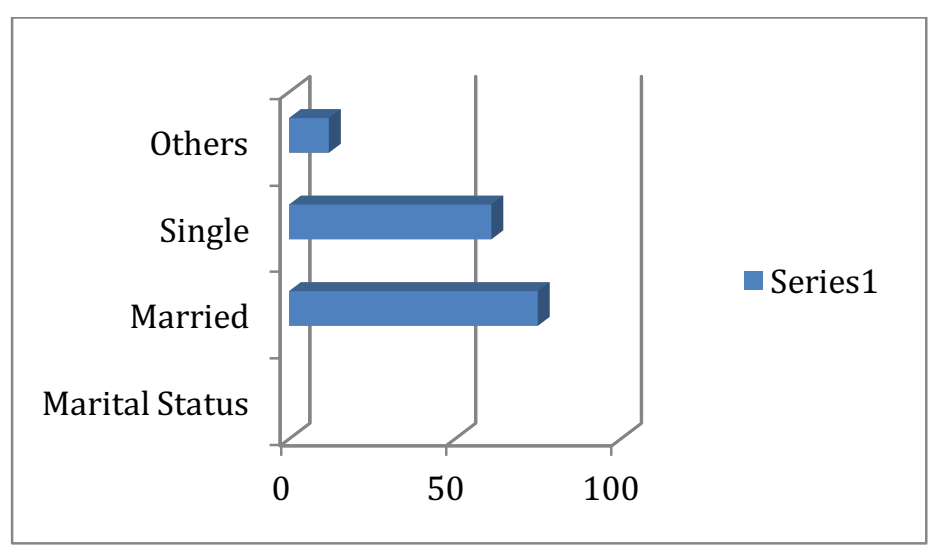

Figure 4.5: Bar chart showing marital status of the respondents

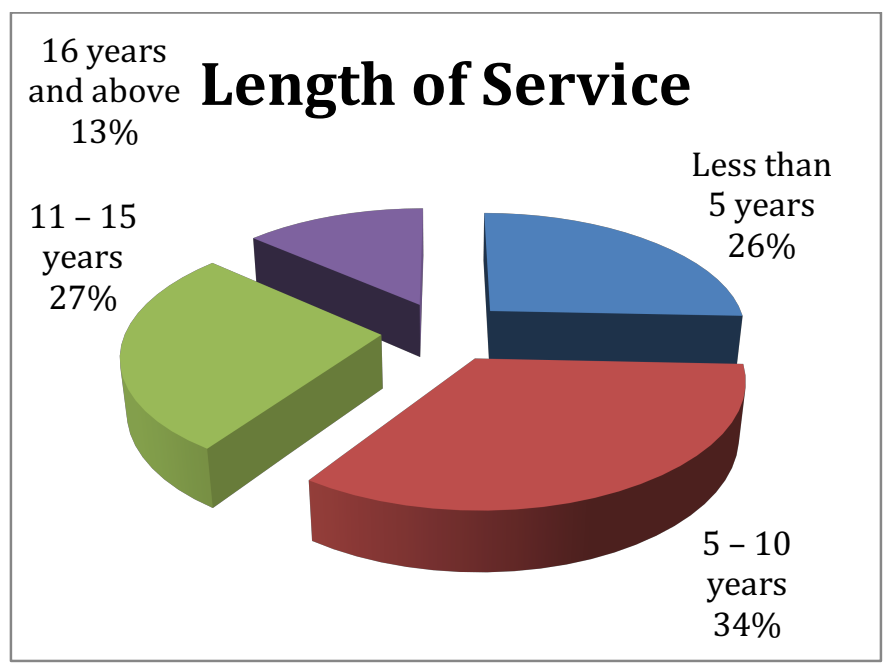

Figure 4.6: Pie chart showing respondents' length of stay in the companies

Table 5 and figure 4.2 show that 80 (54\%) respondents and 68(46\%) respondents were males and females respectively. Also, Figure 4.3 disclosed that $29(20 \%)$ respondents, $34(23 \%)$ respondents, $49(33 \%)$ respondents and 36 (24\%) respondents were in the age brackets of 18-25, 26-35, 36-45 and 46 and above respectively. Again, item three in the table and figure 4.4 revealed that $56(45 \%)$ respondents, $47(32 \%)$ respondents, 30(20\%) respondents and $5(3 \%)$ respondents had, O'Level/ND, B.Sc./HND, Masters and above and other educational qualifications respectively. Also, figure 4.5 shows that 75 (51\%) respondents, 61(41\%) respondents and 12 (8\%) respondents were married, single and others respectively. Moreover, it was revealed through the last item in the table and figure 4.6 that 38 (26\%) respondents, 50 (34\%) respondents and 40 (27\%) respondents and $20(13 \%)$ respondents had been in their respective companies for a period of less than 5 years, 6 to 10 years, 11 to 15 years and 16 years and above, respectively.

\section{Analysis of Major (Research) Variables}

In this section, responses to the main questions were analyzed.

Table 4.6: Responses to whether the companies pay taxes

\begin{tabular}{|c|c|c|}
\hline Option & Frequency & Percentage \\
\hline Yes & 148 & 100.00 \\
\hline No & 0 & 0.00 \\
\hline Not sure & 0 & 0.00 \\
\hline
\end{tabular}

Source: Field survey, 2018

Table 6 shows that all the respondents, representing 100\%, identified that their companies pay taxes. 
Table 7:Responses to Performance Questions

\begin{tabular}{|l|l|c|c|c|c|c|c|}
\hline S/N & Statement & SA & A & UN & D & SD & Total \\
\hline (a) & The tax system affects my profitability. & 98 & 21 & 14 & 10 & 5 & $\mathbf{1 4 8}$ \\
\hline (b) & The tax system influences my sales revenue. & 58 & 64 & 16 & 6 & 4 & $\mathbf{1 4 8}$ \\
\hline (c) & The tax system affects my customer base. & 66 & 42 & 24 & 9 & 7 & $\mathbf{1 4 8}$ \\
\hline (d) & $\begin{array}{l}\text { The tax system influences the number of employees I can } \\
\text { influence. }\end{array}$ & 104 & 31 & 8 & 3 & 2 & $\mathbf{1 4 8}$ \\
\hline (e) & The tax system affects my business expansion rate & 108 & 28 & 6 & 4 & 2 & $\mathbf{1 4 8}$ \\
\hline & Total & $\mathbf{4 3 4}$ & $\mathbf{1 8 6}$ & $\mathbf{6 8}$ & $\mathbf{3 2}$ & $\mathbf{2 0}$ & $\mathbf{7 4 0}$ \\
\hline & Average Total & $\mathbf{8 7}$ & $\mathbf{3 7}$ & $\mathbf{1 4}$ & $\mathbf{6}$ & $\mathbf{4}$ & $\mathbf{1 4 8}$ \\
\hline & Percentage & $\mathbf{5 9}$ & $\mathbf{2 5}$ & $\mathbf{9}$ & $\mathbf{4}$ & $\mathbf{3}$ & $\mathbf{1 0 0}$ \\
\hline
\end{tabular}

Source: Field Survey, 2018

The information is further presented in figure 4.7 as shown below:

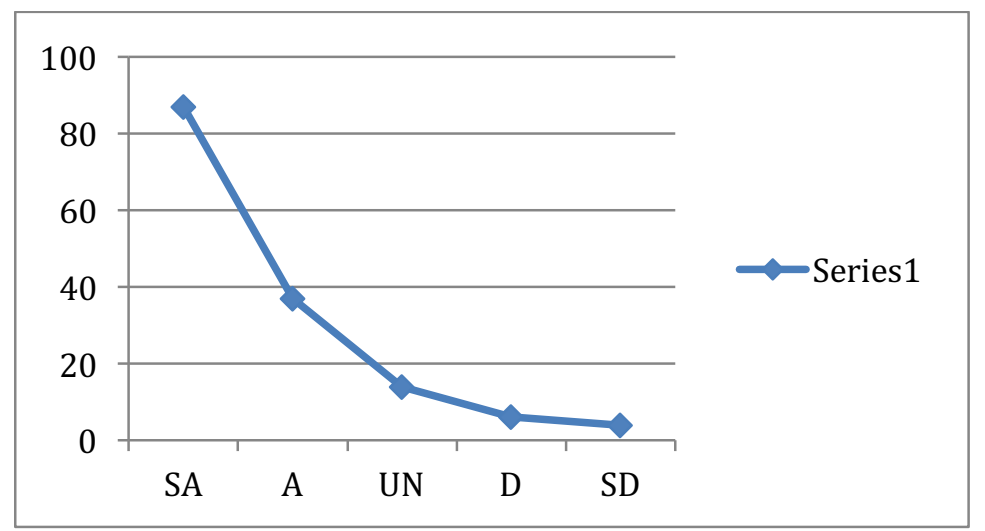

Figure 4.7: Line graph showing responses to performance questions

Table 7 and figure 4.7 show that an average of 87 (59\%) respondents, 37 (25\%) respondents, $14(9 \%)$ respondents, 6 (4\%) respondents and 4 (3\%) respondent strongly agreed, agreed, had not decided, disagreed and strongly disagreed respectively on statements about the effect of taxation on business performance.

Table 8: Responses to Tax Assessment Questions

\begin{tabular}{|c|c|c|c|c|c|c|c|}
\hline $\mathbf{S} / \mathbf{N}$ & Statement & SA & $\mathbf{A}$ & UN & D & SD & Total \\
\hline (a) & The method of tax system on my firm is satisfactory. & 18 & 32 & 20 & 68 & 10 & 148 \\
\hline (b) & The tax assessment in place is objective. & 8 & 37 & 13 & 12 & 78 & 148 \\
\hline (c) & The tax assessment is considerate. & 14 & 27 & 16 & 82 & 9 & 148 \\
\hline & Total & 40 & 96 & 49 & 162 & 97 & 444 \\
\hline & Average Total & 13 & 32 & 16 & 54 & 32 & 148 \\
\hline & Percentage & 09 & 22 & 11 & 36 & 22 & 100 \\
\hline
\end{tabular}

\section{Source: Field Survey, 2018}


The information is further shown in figure 4.8 thus:

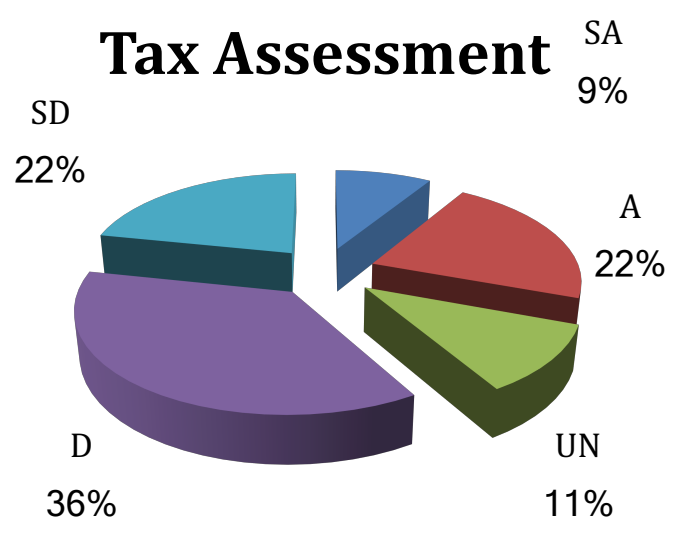

Figure 4.8: Pie chart showing responses to tax assessment questions

Information displayed in table 4.5 and figure 4.8 show that on the average, $13(9 \%)$ respondents, $32(22 \%)$ respondents, $16(11 \%)$ respondents, $54(36 \%)$ respondents and 32 $(22 \%)$ respondent strongly agreed, agreed, had not decided, disagreed and strongly disagreed respectively on statements about tax assessment.

Table 9: Responses to Tax Collection Questions

\begin{tabular}{|l|l|c|c|c|c|c|c|}
\hline S/N & Statement & SA & A & UN & D & SD & Total \\
\hline (a) & I am satisfied with the way taxes are collected from my company. & 24 & 47 & 13 & 7 & 57 & $\mathbf{1 4 8}$ \\
\hline (b) & The method of tax collection is objective. & 31 & 33 & 10 & 8 & 66 & $\mathbf{1 4 8}$ \\
\hline (c) & The method of tax collection is friendly & 11 & 40 & 31 & 16 & 50 & $\mathbf{1 4 8}$ \\
\hline & Total & $\mathbf{6 6}$ & $\mathbf{1 2 0}$ & $\mathbf{5 4}$ & $\mathbf{3 1}$ & $\mathbf{1 7 3}$ & $\mathbf{4 4 4}$ \\
\hline & Average Total & $\mathbf{2 2}$ & $\mathbf{4 0}$ & $\mathbf{1 8}$ & $\mathbf{1 0}$ & $\mathbf{5 8}$ & $\mathbf{1 4 8}$ \\
\hline & Percentage & $\mathbf{1 5}$ & $\mathbf{2 7}$ & $\mathbf{1 2}$ & $\mathbf{0 7}$ & $\mathbf{3 8}$ & $\mathbf{1 0 0}$ \\
\hline
\end{tabular}

\section{Source: Field Survey, 2018}

Figure 4.9 further displays the above information using a column graph.

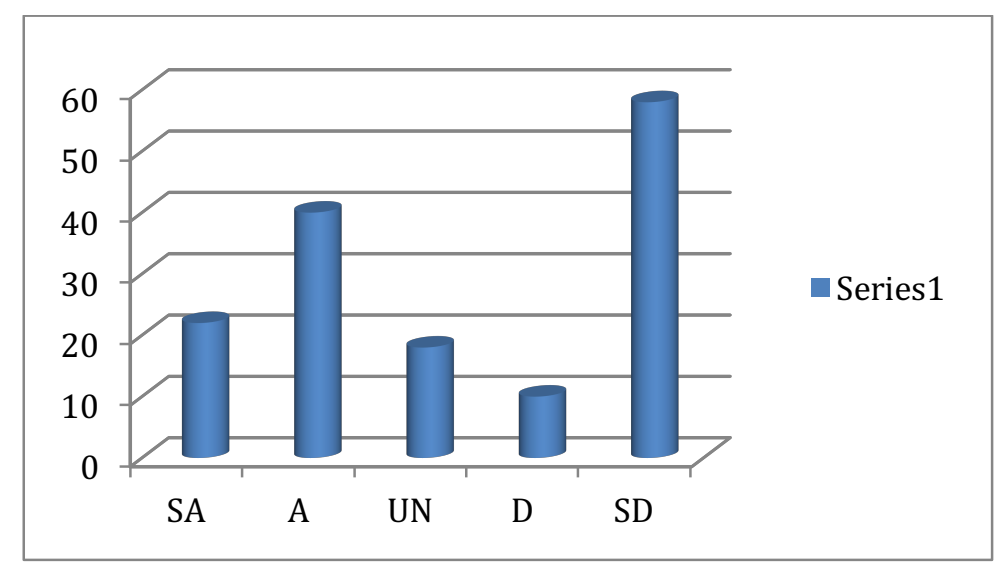

Figure 4.9: Column graph showing responses to tax collection questions

Table 9 and shows that on the average, 22 (15\%) respondents, 40 (27\%) respondents, 18 (12\%) respondents, 10 (7) respondents and 58 (38\%) respondent strongly agreed, agreed, had not decided, disagreed and strongly disagreed respectively on statements about tax collection. 
Table 10: Responses to Tax utilization Questions

\begin{tabular}{|l|l|c|c|c|c|c|c|}
\hline S/N & Statement & SA & A & UN & D & SD & Total \\
\hline (a) & I am satisfied with the way taxes collected are utilized & 11 & 47 & 32 & 16 & 42 & $\mathbf{1 4 8}$ \\
\hline (b) & $\begin{array}{l}\text { Taxes are used to provide needed infrastructure for the } \\
\text { growth of our firms. }\end{array}$ & 10 & 25 & 29 & 44 & 40 & $\mathbf{1 4 8}$ \\
\hline (c) & Taxes are efficiently used by the government. & 21 & 32 & 21 & 34 & 40 & $\mathbf{1 4 8}$ \\
\hline & Total & $\mathbf{4 2}$ & $\mathbf{1 0 4}$ & $\mathbf{8 2}$ & $\mathbf{9 4}$ & $\mathbf{1 2 2}$ & $\mathbf{4 4 4}$ \\
\hline & Average Total & $\mathbf{1 4}$ & $\mathbf{3 5}$ & $\mathbf{2 7}$ & $\mathbf{3 1}$ & $\mathbf{4 1}$ & $\mathbf{1 4 8}$ \\
\hline & Percentage & $\mathbf{0 9}$ & $\mathbf{2 4}$ & $\mathbf{1 8}$ & $\mathbf{2 1}$ & $\mathbf{2 8}$ & $\mathbf{1 0 0}$ \\
\hline
\end{tabular}

\section{Source: Field Survey, 2018}

The information above is further shown in figure 4.10 thus:

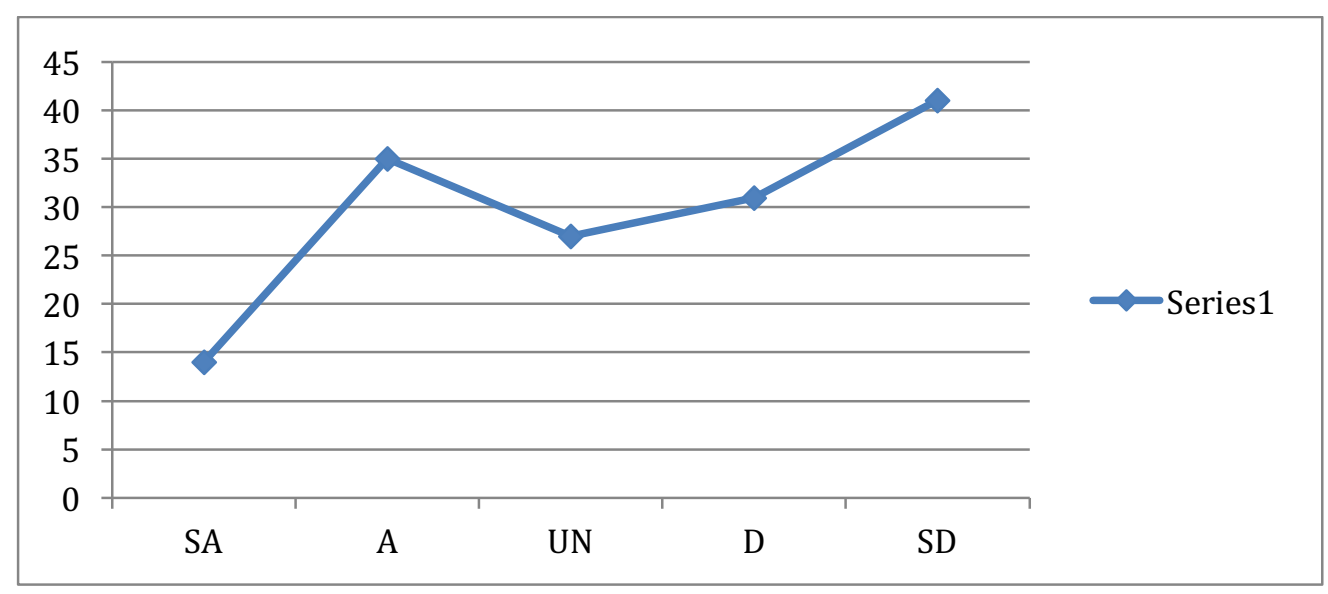

Figure 4.10: Line graph showing responses to tax utilization questions

Table 10 and figure 4.10 show that on the average, 14 (9\%) respondents, 35 (24\%) respondents, $27(18 \%)$ respondents, 31 (21) respondents and 41 (28\%) respondent strongly agreed, agreed, had not decided, disagreed and strongly disagreed respectively on statements about tax utilization.

\section{Result:}

Model Summaryb

\begin{tabular}{|c|c|c|c|c|c|}
\hline Model & $\mathrm{R}$ & $\mathrm{R}$ Square & $\begin{array}{c}\text { Adjusted R } \\
\text { Square }\end{array}$ & $\begin{array}{c}\text { Std. Error of the } \\
\text { Estimate }\end{array}$ & Durbin-Watson \\
\hline 1 & $.745^{\mathrm{a}}$ & .554 & .545 & .66941 & 1.874 \\
\hline
\end{tabular}

a. Predictors: (Constant), Tax Utilization, Tax Collection, Tax Assessment

b. Dependent Variable: Performance of SMEs

ANOVA $^{\mathrm{a}}$

\begin{tabular}{|rl|r|r|r|r|r|}
\hline Model & Sum of Squares & df & Mean Square & \multicolumn{1}{c|}{ F } & Sig. \\
\hline \multirow{2}{*}{1} & Regression & 80.249 & 3 & 26.750 & 59.695 & $.000^{\mathrm{b}}$ \\
& Residual & 64.528 & 144 & .448 & & \\
& Total & 144.777 & 147 & & & \\
\hline
\end{tabular}

a. Dependent Variable: Performance of SMEs

b. Predictors: (Constant), Tax Utilization, Tax Collection, Tax Assessment 


\begin{tabular}{|c|c|c|c|c|c|c|}
\hline \multicolumn{7}{|c|}{ Coefficients $^{a}$} \\
\hline \multirow{2}{*}{\multicolumn{2}{|c|}{ Model }} & \multicolumn{2}{|c|}{ Unstandardized Coefficients } & \multirow{2}{*}{$\begin{array}{c}\text { Standardized } \\
\text { Coefficients } \\
\text { Beta }\end{array}$} & \multirow[t]{2}{*}{$\mathrm{T}$} & \multirow[t]{2}{*}{ Sig. } \\
\hline & & $\mathrm{B}$ & Std. Error & & & \\
\hline \multirow{4}{*}{1} & (Constant) & 2.964 & .126 & & 23.558 & .000 \\
\hline & Tax Assessment & .213 & .135 & .333 & 2.158 & .020 \\
\hline & Tax Collection & .249 & .107 & .391 & 2.330 & .021 \\
\hline & Tax Utilization & .359 & .168 & .490 & 2.133 & .035 \\
\hline
\end{tabular}

a. Dependent Variable: Performance of SMEs

Interpretation: The $\mathrm{R}$ value $(0.745)$ shows that a strong, positive and significant relationship exists between taxation and online SMEs performance. The adjusted $\mathrm{R}^{2}$ value $(0.545)$ reveals that $54.5 \%$ variation in performance is predicted by taxation. Also, the F value (59.70) and p value (0.000) which are greater than $f$ critical value at 0.05 level of significance (6.39) and less than alpha (0.05) respectively are positive signs of relationship. The coefficients table shows that tax assessment $(\mathrm{t}=2.158 ; \mathrm{p}=0.020)$ and tax collection $(\mathrm{t}=2.330 ; \mathrm{p}=0.021)$ and tax utilization $(\mathrm{t}=2.133 ; \mathrm{p}=0.035)$ significant predictors of performance. This is because their p-values are less than alpha (0.05) and their $\mathrm{t}$-values greater than $\mathrm{t}$-critical.

Decision: Based on the above outcomes, we therefore reject the null hypothesis and accept the alternate which implies that there is a significant and positive relationship between taxation and SMEs performance..

\section{SUMMARY OF FINDINGS}

Based on the analyzed data, the following key findings were made in this study;

- It was discovered that there is a positive and significant relationship between taxation and the performance of SMEs.

- It was equally discovered through the study that tax assessment significantly affects the performance of SMEs.

- Also, it was discovered through the study that tax collection system significantly affects the performance of SMEs.

- And that that tax utilization system significantly affects the performance of SMEs.

\section{CONCLUSION}

Based on the findings of the study, we can conclude that taxation is a key factor in the financial life of any SME. For the SMEs to perform satisfactorily, the tax system in place must promote the survival of such firms. Thus, the tax collection, assessment and utilization must be SMEs oriented as this will in turn impact on the growth of the economy.

\section{RECOMMENDATIONS}

The following are some of the recommendations from this study:

- Nigerian tax system must seek to protect and promote the SMEs for them to contribute meaningfully to economic growth.

- It is also advisable to identify the agents responsible for illegal, multiple tax collections that seek to frustrate SMEs and deal with them accordingly.

- In order to give back to the tax payers and promote SMEs, the government at all levels must judiciously utilize taxpayers' money. 


\section{References}

Agu, G.A (2015) Customer-complaint Behaviour in the service industry; A study of the customers of the organised Road Transport Firms In Imo State. A ph.D Thesis, Abia State University, Nigeria.

Aham Anyanwu (1998) Marketing in action. Owerri; Klet-ken publisher.

Aham Anyanwu (2003) Promotional strategy- A schematic Approach. Owerri; Avan Global publications.

Aham Anyanwu (2013) Marketing Management and Strategy. Owerri: Avan Global Publications.

Aham Anyanwu (2000) Dimension of Marketing. Owerri; Avan Global Publications.

Anyanwuocha, R.A.I (2005) Fundamentals of Economics for Senior Secondary Schools. Abuja; Africa First Publishers Ltd.

Avery, J. (2009) Student-run advertising agency. A show case for student work. Retrieved $20^{\text {th }}$ April 2012.

Awa I. and Kalu I. N. (2016) Marketing Communications: An integrated Approach. Nationwide Printers and Publications.

Chinedu N. O (2013) Marketing Research Port-Harcourt: African Entrepreneurship and Leadership Initiative (AELI).

Doughudje C. (1993) Creativity in Advertising: Journal of Marketing Management, Enugu Nigeria, University of Nigeria.

Ezejelue A.C, Ogwo E.O, and Nkamnebe A.D (2017) Basic Principles in Managing Research Projects.Aba: Afritowers Ltd.

Gotoh N and Wada S. (2005) The importance of peroxide value in accessing good quality and food, safety journal of the American oil chemists society 473-474 doi 10.1007151176806-1229.

Inyanga J (1998) Nigerian Marketing System. The marketing mix Approach. Global press limited.

Kaiser, u. and Song, M (2009) “ Do media consumers really dislikeadvertising. An empirical assessment of the role of advertising in electronic media marketer. International journal of Industrial Organisation22(2).

Kotler P. Armstrong G Saunders J and Wong U (2006) Principles of Marketing, New Jersey: Prentice Hall Inc.

Nwaizigbo, I.C(2004) Principles of Marketing. Enugu: New generation books.

Okpara, G.S (2012) Contemporary Marketing: Topical and Tropicalised. Owerri: Avan Global Publications.

Okpara, G.S, Anyanwu, A and Inyanga J.I (1999) Marketing Communication principles and practices; Portharcourt Educational Books and investment.

Okpara, G.S and Agu G.A (2016) Intermediate Marketing; Bridging the gap between foundational and special marketing thoughts. Owerri: Avan Global Publications.

Onah, J.O and Thomas, M.J (2004) Marketing Management: Strategies and cases. Enugu. Institute for Development Studies.

Stephen, D (2010) Measuring Situational triggers of television advertising for avoiding ads by fast-forwarding through commercials. Retrieved 21 ${ }^{\text {st }}$ April 2012.

Wikipedia (2018) Frequency of television advertising http://em.M-wikipedia.org/wiki/effective frequency. Retrieved on 12 July 2018.

Wikipedia(2018)Consumption.http://en.m.wikipedia.org/wikiconsumption.Retrieved on 12 July 2018.

William, F. A (2006) Advertising. Irwin: McGraw Hill. 